\title{
The Analysis of Student's Writing By Using Systemic Functional Grammar
}

\author{
Fauziah $^{1} \& \operatorname{Ramlan}^{1 *}$ \\ 1Department of English Education, Universitas Jabal Ghafur, Pidie, Aceh, Indonesia \\ fziah05@yahoo.com; ramlan@unigha.ac.id \\ *Corresponding Author
}

How to Cite : Fauziah \& Ramlan. (2020). The Analysis of Student's Writing By Using Systemic Functional Grammar. International Journal for Educational and Vocational Studies, 2 (2), 158-164. DOI: https://doi.org/10.29103/ijevs.v2i2.2281

\section{ARTICLE HISTORY}

Received:14 November 2019

Revised: 28 December 2019

Accepted: 22 January 2020

\section{KEYWORDS}

Systemic Functional Grammar; Review Text;

Text Analysis;

\section{ABSTRACT}

This study is discussed about an analysis of a review text entitled Leonardo Da Vinci written by one of first grade student of a senior high school in Bandung. It consists of three parts: introduction, discussion and conclusion. The introduction describes the lexicogrammatical features of student's Review text. The discussion provides the analysis of Theme system, Transitivity system, Modality and Grammatical metaphor by using Systemic Functional Grammar. Finally, the conclusion sums up the result of the analysis and briefly explains implication of the topic. He organized the text successfully that achieved the purpose, generic structure and linguistic feature of review text in general.

This is an open access article under the CC-BY-SA license.

\section{INTRODUCTION}

\section{Theme System}

From the Theme System, the text will be seen from several aspect types of Theme, boundary of Themes, longer unit Themes, higher level Themes and thematic progression. The first discussion is related to the boundary of Themes. Eggin (1994) stated that there are three different types of Themes: topical (experiential), interpersonal, and textual elements. Lovejo and Lance (1991) in their study of written Discourse, show that Theme is "the point of departure for the presentation of information ...". Identifying clauses highlight the theme in that they function to express the Theme-Rheme structure in such a way as to foreground the theme by making any of the elements of the clause the theme (Halliday 2000:42 see also Opara, 2012).

The theme of a sentence is the word or phrase that begins the sentence. If the sentence beginnings all relate to the main idea of the paragraph it is easier for the reader to focus on that idea. Human psychology in the reading process is the main focus then it will be more natural to look at coherence. It means that the text is coherence. Lovejoy and Lance (1991) written that cohesion can be achieved through the operation of theme-rheme. This movement represents how information is managed.

According to Lovejoy and Lance, theme is "the - point of departure for the presentation of information," and rheme "constitutes the information the writer wishes to impart about the theme". These two elements are presented alternatively in a text to form a connected text. While theme conveys information that is initially introduced in discourse, rheme presents specific information regarding the theme. As this movement continues, ideas in a text or discourse are expected to flow along smoothly and are easier for the reader to understand. While old information (theme) is presented as background information in each statement, new information (rheme) is introduced to clarify the information in the theme.

The next discussion is related to the longer unit Themes. From the work of Halliday (1994, p. 54-61) and Martin, Mathiessen and Painter (1997, p. 35), longer unit Themes found in the texts can be realised in: (17) Embedded clauses (Wh-clauses, non-finite, and that-clauses); (9, 14, 17) Long nominal groups, including those which extend beyond the main noun, and which may involve clause embedding. The last discussion is related to the higher level Themes (Macro- and Hyper-Themes). The information and opinions about issues is an issue ('For/Pros' and 'Against/Cons'). This element can 
successfully function as "the opening generalisation in the text which predicts its overall development" (Coffin, 1997: 218 and see also Emilia, 2010: 82). The issue possibly predicts a set of hyper-Themes that what we called as macro-Theme. This is the introductory paragraph of school rhetoric (Martin, 1992: 437; 2002, see also Martin and Rose, 2003; Coffin, 1997: 218-219 cited in Emilia, 2010).

\section{Transitivity System}

As a part of English linguist M.A.K. Halliday's systemic-functional grammar (1985;1994), the lexicogrammatical category of transitivity enables the analysis of the experiential function of people's perception of the world. It can be elaborated through the way they use language. As Halliday puts it, 'language enables human beings to build a mental picture of reality, to make sense of what goes on around them and inside them' (1994: 106).

The main argument of the transitivity system is that the experiences go through life consists of 'goings-on' happening, doing, sensing, meaning, being and becoming' (1994:106). The transitivity system are shared by people through clauses that constitute language they use to communicate. According to the way how people view the world, they will express themselves in particular ways, which in the transitivity system are called processes (Cristina, 2006). The verbs can be classified in six processes in transitivity system. They are material, verbal, relational, behavioral and existential. The most important ones which are analyzed in the excerpts taken from the student's review text are the material, the mental and the relational processes.

\section{Modality}

The modality traditionally is focused on modal auxiliaries, that is on grammaticalized modal expressions empirical basis for the linguistic study of modality has been widened as a result ofthe greater interest in exploring the functions and uses of modal expressions. There are four different expression of modality; modal adverbs, modal adjectives, mental state predicates and modal auxiliaries (Nuyts 2001: 29). Perkins (1983: 2) argues the range of modal phenomena also made it clear that "no two modal expressions could be said to have exactly the same meaning." Furthermore, Hunston (2011: 66) states that it is a need to recognize modal-like expressions appearing in contexts that signal modal meanings.

According to Nuyts (2001: 7), "the functionalist tenet is understood as a methodological directive to uncover functional motivations for linguistic forms and structures in grammar and in discourse." Modality should be studied both formally and functionally and, additionally, function should be able to explain the distribution of forms. An important consequence of the functional perspective is that modality and mood should be described across a wide range of language types so that the definition of modality is given a typological dimension. In a pioneering study, Palmer (1986) laid the groundwork for a functional-typological perspective in research on modality and mood. Although the enterprise was not carried out systematically, Palmer (1986: 2) showed that the category of modality can and should be "identified, described and compared across languages.” (Aijmer, 2016)

\section{Grammatical Metaphor}

It is against the background of lexical metaphor that Michael Halliday, the founder of systemic functional linguistics, has introduced the notion of 'grammatical metaphor' in the early 1980s (see e.g. Halliday 1985). As typical instances of grammatical metaphor, Halliday considers various types of nominalizations.

Grammatical metaphor again involves a type of metaphorical movement: from a process as clause (the default encoding of a process) to a process as noun phrase. Grammatical metaphor is thus based on the variation between something common, standard, default and something which is extended from that and in this sense grammatical metaphor is similar to the traditional type of metaphor looked at above. However, in the case of grammatical metaphor, the two aspects involved in the movement or metaphorical extension no longer refer to lexemes and lexical meanings. Rather, they refer to grammatical forms, or grammatical means of expression, such as a clause and a nominal group. These two aspects (i) the metaphorical movement and (ii) the variation between grammatical forms - explain the two parts of the notion 'grammatical metaphor'. In order to appreciate the importance and wide-spread nature of grammatical metaphor, however, it is necessary to first have a look at some general features of systemic functional linguistics in relation to which the phenomenon can be explained. (Taverniers, 2004).

The study is aimed to provide the analysis of Theme system, Transitivity system, Modality and Grammatical metaphor by using Systemic Functional Grammar.

\section{METHODS}

This study used descriptive method to give a detailed description of Theme system, Transitivity system, Modality and Grammatical metaphor by using Systemic Functional Grammar. The study analyzed student's review text about a book entitled Seri Tokoh Dunia: Leonardo Da Vinci by Lin Jui Hwa.

\section{RESULTS AND DISCUSSION}

\subsection{Results}

The tables show the result of the analysis of Theme system, Transitivity system, Modality and Grammatical metaphor by using Systemic Functional Grammar. 


\begin{tabular}{|c|c|c|c|c|}
\hline & This book & Tells & about Leonardo Da Vinci \\
\hline & Subject & Finite & Predicator & Residue \\
\hline & Sayer & \multicolumn{2}{|c|}{ Pro: Verbal } & Receiver \\
\hline & Rood & \multicolumn{2}{|c|}{ Rh } \\
\hline
\end{tabular}

\begin{tabular}{|c|c|c|c|c|}
\hline & [[who & \multicolumn{2}{|c|}{ painted } & Monalisa picture]] \\
\hline & & Finite & Predicator & Complement \\
\hline & \multicolumn{2}{|l|}{ Mood } & \multicolumn{2}{|c|}{ Residue } \\
\hline & Actor & \multicolumn{2}{|c|}{ Pro: Mat } & Goal \\
\hline \multicolumn{2}{|c|}{ Unmarked Top. Th } & \multicolumn{3}{|c|}{$\mathrm{Rh}$} \\
\hline
\end{tabular}

\begin{tabular}{|c|c|c|c|c|}
\hline & Leonardo Da Vinci & was & Born & in Vinci, Italia. \\
\hline & Subject & Finite & Predicator & Adjunct (Cir: place) \\
\hline & Goal Mood & \multicolumn{2}{|c|}{ Pro: Mat } & Circ. Location \\
\hline & \multicolumn{2}{|c|}{ Rh } \\
\hline
\end{tabular}

\begin{tabular}{|c|c|c|c|}
\hline & The picture painted by him & is & Last Supper \\
\hline & Subject & Finite & Complement \\
\hline & \multicolumn{1}{|c|}{ Mood } & Residue \\
\hline & Value & Pro: Rel & Token \\
\hline
\end{tabular}

\begin{tabular}{|c|c|c|c|c|}
\hline & The Last supper picture & \multicolumn{2}{|c|}{ Told } & about Jesus and the 12 disciples. \\
\hline & Subject & Finite & Predicator & Adjunct \\
\hline & \multicolumn{3}{|c|}{ Mood } & Residue \\
\hline & Sayer & \multicolumn{2}{|c|}{ Pro: Verbal } & Target \\
\hline \multicolumn{2}{|r|}{ Th } & \multicolumn{3}{|r|}{$\mathrm{Rh}$} \\
\hline
\end{tabular}

\begin{tabular}{|c|c|c|c|}
\hline & This picture & Was & very famous especially in film 'The Da Vinci Code'. \\
\hline & Subject & Finite & Complement \\
\hline & & Residue \\
\hline & Carier & Pood Attr & Attribute \\
\hline & & & Rh \\
\hline Top. Th
\end{tabular}

\begin{tabular}{|l|c|c|c|c|}
\hline \multirow{2}{*}{ Not only art, } & Da Vinci & \multicolumn{2}{c|}{ Learned } & more subjects such as Math, Geography and Physical \\
\hline & Subject & Finite & Predicator & Complement \\
\hline & \multicolumn{2}{|c|}{ Mood } & \multicolumn{2}{c|}{ Pro: Mat } \\
\hline \\
\hline
\end{tabular}

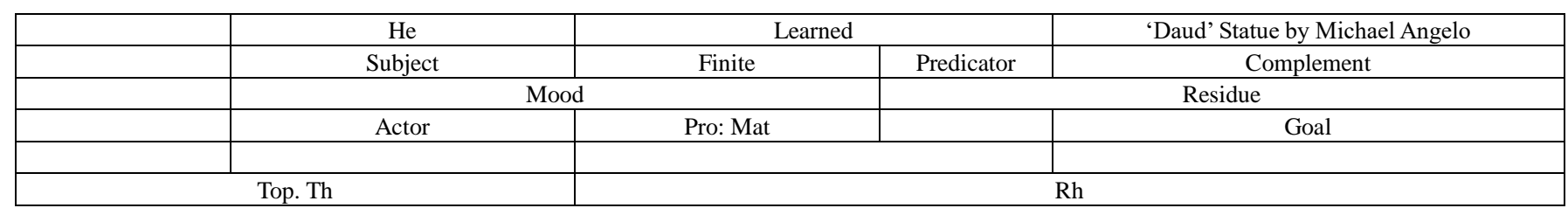

\begin{tabular}{|c|c|c|c|}
\hline & One of Da Vinci's popular painting (paintings) & was & Monalisa \\
\hline & Subject & Finite & Complement \\
\hline & Token Mood & Pro: Int & Vesidue \\
\hline & Value \\
\hline
\end{tabular}




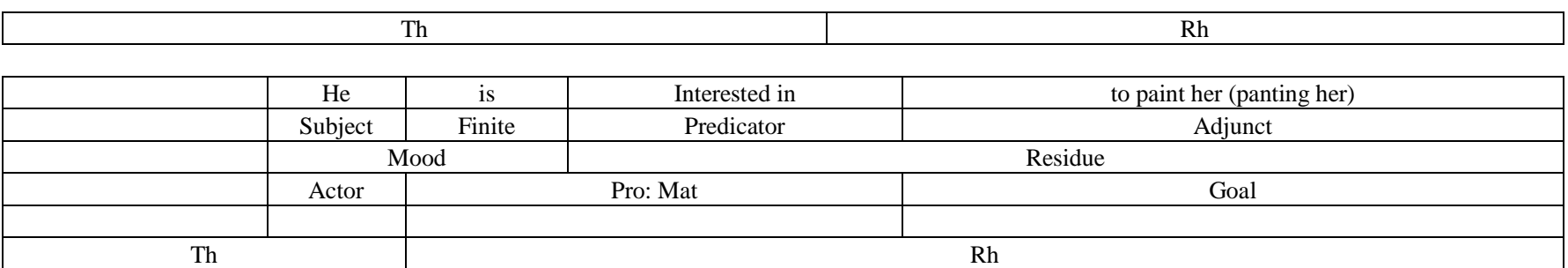

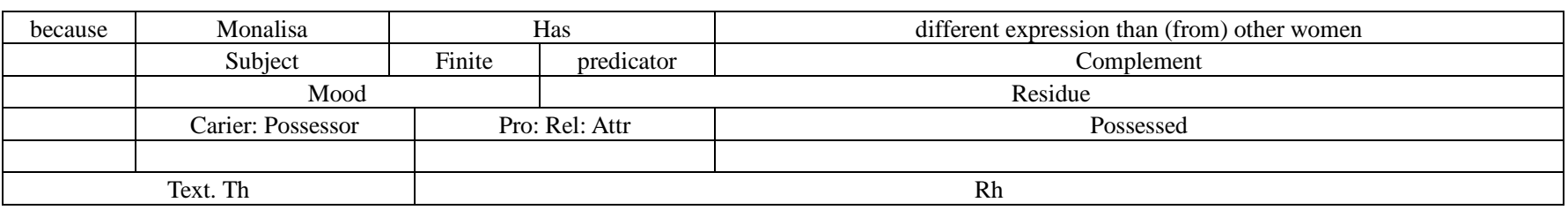

\begin{tabular}{|c|c|c|c|c|}
\hline & I & \multicolumn{2}{c|}{ Like } & Complement \\
\hline & Subject & Finite & Predicator & Residue \\
\hline & \multicolumn{2}{|c|}{ Mood } & Pro: Men & Phen \\
\hline & Senser & \multicolumn{2}{c|}{ Rh } \\
\hline
\end{tabular}

\begin{tabular}{|l|c|c|c|c|c|}
\hline & This book & \multicolumn{2}{|c|}{ have (has) } & many illustration & about Da Vinci's paintings \\
\hline & Subject & Finite & Predicator & Complement & Residue \\
\hline & \multicolumn{2}{|c|}{ Mood } & \multicolumn{2}{|c|}{ Possessed } \\
\hline & possessor & \multicolumn{2}{|c|}{ Pro: Poss } & \multicolumn{2}{|c|}{ Rh } \\
\hline
\end{tabular}

\begin{tabular}{|c|c|c|c|}
\hline & They & aren't & colourful (colorful) \\
\hline & Subject & Finite & Complement \\
\hline & & & Residue \\
\hline & Carier & Pood & Pttr \\
\hline & & & Rht \\
\hline
\end{tabular}

\section{Lexicogrammatical Features of Student's Review Text}

Review text is a text to critique an art work or event for public audiences (Gerot \& Wignell, 1994: 217, Suherdi, 2013: 91). The text tells about Leonardo Da Vinci's biography. This text has achieved its purpose in fulfilling four generic structures of Review text. They are orientation, interpretative recount, evaluation, and evaluative summation. This indicates that the writers has already understood and mastery the Review text. However, this essay still has grammatical error in term of expressing idea and sentence structures. Probably, it is because of the text is not a final draft but still in progress of revising.

\subsection{Discussion}

As indicated above, the discussion focuses on the analysis of Theme system, Transitivity system, Conjunction system, Modality and Grammatical metaphor by using Systemic Functional Grammar. Further explanation and discussion of each system will be elaborated below.
Analysis of Theme System

Theme system concerns the organization of the information within clause and text (Martin, Matthiessen $\&$ Painter, 1997). The theme systems have two levels namely theme and rheme. There are four aspects of Theme that will analyze. They are higher-level Theme, thematic progression, types of Themes, and longer unit Themes. Theme system is the stating point of a clause (Martin et al., 1997 \& Butt at al., 2000; Halliday \& Matthiessen, 2004, see also Eggins, 2004).

The first analysis is related to higher-level Themes. Macro-theme is one type of higher-level Themes. It has successfully been represented by the orientation of the text. Emilia (2010: 82) stated the overall development and the upcoming theme as well as gives structure and order of the text. The macro-theme as in: "This book tells about Leonardo Da Vinci who painted Monalisa picture" shows that the text will focus on Leonardo Da Vinci and his painted picture, Monalisa.

This macro-theme predics and constitutes two hyper-Themes including summarize of the plot (Leonardo Da Vinci's biography) and his masterpiece (Monalisa). It cannot easily find in the text because this is not Discussion text which shows ordinal number (first, second, trird, ...). In Review text, macro-theme is built-in sequence 
of idea in the orientation of the text.

The second analysis is regarding the thematic progression. There are three types of the patterns that used in the thematic progression; reiteration, zig-zag and multiple theme patterns (Emilia: 2010: 22-23). But, in the text it was found two patterns as in below;

This book tells about Leonardo Da Vinci who painted Monalisa picture.

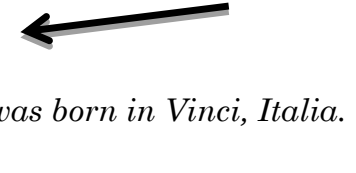

Leonardo Da Vinci was born in Vinci, Italia.

He comes from poor family

(The zig-zag and reiteration pattern)

It shows that the writer is able to maintain the connection within clauses in the Review text to indicate the global and local cohesion of the text (Emilia, 2010: 22-23). The third analysis is concerned the types of themes. There are two types of themes was found in the text (topical theme (unmarked and marked), and textual theme). Unmarked and marked topical themes have been used in preview of focus that will be discussed. As stated below:

This book tells...

Leonardo Da Vinci was...

\section{The picture was...}

Textual theme successfully used as the cohesive devices in both of the elements to make the clauses move forward easily in clear logical connection (Eggins as cited in Emilia, 20: 19). There are found in the text;

Not only art, ...

After, ...

But, ...

At last, the text has successfully used longer unit theme (Emilia, 2010: 20) as in the following discussion:

The Last supper picture told ...

One of Da Vinci's popular painting (paintings) was ...

By using longer unit theme in the text, it shows that the writer is able to use a more complex phrase or clause in expressing his capability in writing.

\section{Analysis of Transitivity System}

Transitivity system will analyze based on three categories: process, Participant and circumstance. The first category refers to Process types.

Table 1. Analysis of Transitivity System of student's review text

\begin{tabular}{cccccccc}
\hline \multirow{2}{*}{ Process types } & \multirow{2}{*}{ Material } & \multirow{2}{*}{ Mental } & \multirow{2}{*}{ Verbal } & \multicolumn{3}{c}{ Relational } & \multicolumn{2}{c}{ Behav } \\
\cline { 3 - 7 } & & & 3 & 3 & Intensive & Cause & \\
\hline Total & 10 & 3 & 6 & 2 & - \\
\hline
\end{tabular}

From the table, it shows that there are three mental and eight relational processes. This suggest that the text reflect the significant lexicogrammatical feature of a Review genre as the direct expression of options through use of Attitudinal Epithets in nominal groups; qualitative Attributes and Affective Mental Processes, focus on particular participants, use adjectives showing attitude, use of long and complex clauses, use of metaphorical language (Gerot \& Wignell, 1994: 218).

Affective Mental Processes as shows below:

I like this book. This book have (has) many illustration about Da Vinci's paintings but they aren't colourful (colorful). So, the children bored to read this book. In this book, I can learn to study about something new beside things [[that I like The cover of this book is interesting]]. (more than just its interesting cover)

The focus on particular participants that shows below:

Leonardo Da Vinci was born in Vinci, Italia. He (comes) from poor family. After he became teenager, he went to Florence to study about art. The picture was painted $($ was = Q) by him is Last Supper. The Last supper picture told about Jesus and the 12 disciples. This picture was very famous especially in film 'The Da Vinci Code'. Not only art, Da Vinci learned more subjects such as Math, Geography and Physical. He learned 'Daud' Statue by Michael Angelo.

One of Da Vinci's popular painting (paitings) was Monalisa. He interested to paint her because Monalisa has different expression than other women. Da Vinci spend (spends) his old age with Melzi in Amboise, France with his student Francesco Melzi. In 1519, Da Vinci passed away.

Use of long and complex clauses for instance; "The Last supper picture told ...", "One of Da Vinci's popular painting (paintings) was ...". Then the use of metaphorical language such as it's interesting cover. Using those kinds of linguistic features indicate that the writer has the ability to precise the information to clarify the meaning his messages (Hinkel as cited in Emilia, 2010:95).

\section{Analysis of Modality}

Modality has modalization and modulation which realized through modal verbs is inherently "subjective" in their orientation because it is ultimately the speaker who is "responsible" for the assessment of probability, usuality, obligation, and inclination (Halliday \& Matthiessen, 2004; Eggins, 1994; Martin et al., 1997). This subjectivity is manifested "implicitly" in modal verbs, as the role of the speaker/writer in such modal verb-mediated propositional 
judgment is left linguistically implicit, with no corresponding surface form realized to encode such an aspect of the speaker. Given the complexity of skills required to write an effective legal memorandum, however, objective manifestations of modality through other lexicogrammatical resources are also essential for maintaining a genre-appropriate authoritative tone in presenting assessments of legal probability and necessity. In this regard, the higher-ranked writers seem to have a richer repertoire of "implicitly objective" modal expressions in their drafts.

It is clear that modality is "a complex area of English Grammar which concern the different ways in which a language user can intrude on his/ her message, expressing attitudes and judgments of various kind" (Eggins: 1994: 171).

Table 2. Analysis of Modality of student's review text

\begin{tabular}{|c|c|c|c|c|c|}
\hline \multirow{2}{*}{ Sentences } & \multirow{2}{*}{ Orientation } & \multicolumn{3}{|c|}{ Attitude } & \multirow{2}{*}{ Polarity } \\
\hline & & Appreciation & Affect & Judgement & \\
\hline He (comes) from poor family. & Objective & & & $\mathrm{V}$ & Positive \\
\hline $\begin{array}{l}\text { This picture was very famous } \\
\text { especially in film 'The Da Vinci Code'. }\end{array}$ & Objective & V & & & Positive \\
\hline $\begin{array}{l}\text { One of Da Vinci's popular (paitings) } \\
\text { was Monalisa. }\end{array}$ & Subjective & V & $\mathrm{V}$ & & Positive \\
\hline I like this book. & Objective & & & & Positive \\
\hline $\begin{array}{l}\text { This book (has) many illustration } \\
\text { about Da Vinci's paintings but they } \\
\text { aren't (colorful). }\end{array}$ & Objective & $\mathrm{V}$ & & & Positive \\
\hline So, the children bored to read this book. & & & & & Positive \\
\hline $\begin{array}{l}\text { That I like the book more than just its } \\
\text { interesting cover. }\end{array}$ & Subjective & $\mathrm{V}$ & $\mathrm{V}$ & & Positive \\
\hline
\end{tabular}

\section{Grammatical Metaphor}

“The book about background of Leonardo Da Vinci, his life journey and his masterpiece is interesting to read." is grammatical metaphor of text below.

This book tells about Leonardo Da Vinci who painted Monalisa picture.

Leonardo Da Vinci was born in Vinci, Italia. He comes from poor family. After he became teenager, he went to Florence to study about art. The picture painted by him is Last Supper. The Last supper picture told about Jesus and the 12 disciples. This picture was very famous especially in film 'The Da Vinci Code'. Not only art, Da Vinci learned more subjects such as Math, Geography and Physical. He learned 'Daud' Statue by Michael Angelo.

One of Da Vinci's popular paitings was Monalisa. He interested to paint her because Monalisa has different expression than other women. Da Vinci spends his old age with Melzi in Amboise, France with his student Francesco Melzi. In 1519, Da Vinci passed away.

I like this book. This book has many illustrations about Da Vinci's paintings but they aren't colorful. So, the children bored to read this book. In this book, I can learn to study about something more than just its interesting cover.

\section{CONCLUSION}

In conclusion, the writer of this review text is successfully organized the text. He has achieved the purpose, generic structure and linguistic feature of review text in general. However, the feedback and tachers' assistence is needed to develop his skill in writimg. Obviously, systemic functional grammar is important for both teacher and student in order to understand, produce appropriate text and develop critical thinking.

\section{REFERENCES}

Anderson, M. \& anderson, K. (1998). Text types in English. Melbourne: Macmillan.

Aijmer, K. (2016). Modality and mood in functional linguistic approaches Oxford Handbooks Online Modality and mood in functional linguistic approaches, (January). https://doi.org/10.1093/oxfordhb/9780199591435.013. 22Butt, D,

Fahey, R., Feez, S \& Yallop, C. (2000). Using Functional Grammar: An Explorer Guide. $2^{\text {nd }}$ edition. Sydney: National Center for English Language Teaching and 
Research, Macquirie University.

Cristina, B. (2006). Analysis A Literary Work Using Sistemic Functional Grammar. In 33rd International Systemic Functional Congres 2006 (pp. 735-762).

Dewerianka, B. (2004). Exploring How Texts Works. Newtown: PETA

Eggins, S. (1994). An Introduction to Systemic Functional Linguistics. London: Printer Publishers, Ltd.

Emilia, E. (2010). Teaching Writing: Developing Critical Learners, Bandung: RIZQI Press

Emilia, E. (2011). Pendekatan Genre-Based dalam Pengajaran Bahasa Inggris: Petunjuk untuk Guru, Bandung : RIZQI press.

Gerot, L and Wignell, P. (1995). Making Sense of Functional Grammar. Gerd Stabler, Antipodean Educational Enterprises.

Martin, J.R. Matthiessen, C.M.I.M and Painter C. (1997). Working with Functional Grammar. London: Arnold.

Suherdi, D. (2013). Buku Pedoman PenyelenggaraanProfesi Guru Bahasa Inggris. Bahan ajar Pemantapan Kompetensi Akademik, Bandung: Celties Press

Taverniers, M. (2004). Grammatical metaphors in English, (Section 4), 1-11. 